\title{
Samoocena kompetencji językowej młodziėzy z euroregionów pogranicza polsko-czeskiego w zakresie języka sąsiadów
}

Streszczenie: Jeszcze w drugiej połowie XX wieku nauka języków obcych była domeną przede wszystkim ludzi bogatych, wykształconych lub wykonujących specyficzne zawody. Współcześnie - jak można zauważyć - w większości europejskich społeczeństw i w ramach ich polityki oświatowej istotna jest znajomość przede wszystkim takich języków jak: angielski, niemiecki, francuski, łacina oraz - coraz częściej - hiszpański i włoski. Okazuje się, niestety, że znajomość takich języków jak czeski i polski nie jest dla młodych ludzi atrakcyjna. Badana młodzież, z euroregionów z pogranicza polsko-czeskiego, dokonała - za pomocą pięciostopniowej skali - oceny poziomu opanowania swojej kompetencji językowej w zakresie czterech podstawowych sprawności: czytania, rozumienia, mówienia i pisania w języku mieszkańców sąsiedniego państwa (odpowiednio czeskiego/polskiego). Okazało się, że w każdej z poddanych ocenie sprawności językowej zdecydowanie więcej młodych ludzi z Polski niż z Republiki Czeskiej oceniło ich opanowanie na słabym lub bardzo słabym poziomie, a mniej - na dobrym lub bardzo dobrym. Może to być związane z tym - jak pokazały wyniki - że po czeskiej stronie granicy więcej młodzieży ogląda polskie programy lub używa języka w bezpośredniej relacji z sąsiadami.

Aby udoskonalić rozwój tych sprawności, należałoby przede wszystkim zadbać o odpowiednią motywację do nauki tych języków, poprzez stwarzanie młodzieży jak najwięcej możliwości bezpośrednich kontaktów z rówieśnikami zza granicy poprzez organizowanie wymian międzyszkolnych, wyjazdów krajoznawczych, różnego rodzaju warsztatów integracyjnych czy też wspólnych działań artystycznych lub sportowych. Niezwykle istotne jest bowiem dla młodych ludzi, aby powiązać naukę języka obcego z przyjemnością, z poznawaniem nowych ludzi i ich kultury.

Słowa kluczowe: kompetencja językowa, samoocena sprawności językowych, euroregiony pogranicza polsko-czeskiego 


\section{Wprowadzenie}

Jeszcze w drugiej połowie XX wieku nauka języków obcych była domeną przede wszystkim ludzi bogatych, wykształconych lub wykonujących specyficzne zawody. Współcześnie ich znajomość to nie tylko ważne narzędzie w nowoczesnym życiu zawodowym czy przywilej ludzi bogatych lub młodych, ale element dnia codziennego niemal każdego człowieka. Ułatwia komunikację podczas urlopów lub podróży służbowej, pozwala na korzystanie z wielu dostępnych źródeł informacji, a także otwiera możliwości kontaktu z drugim człowiekiem mieszkającym w dowolnym miejscu na świecie. Język to jednak nie tylko narzędzie do przekazu informacji, ale poprzez jego znajomość ludzie poznają kulturę innego narodu, zdobywają na jego temat wiedzę, poprzez bezpośrednią komunikację ze swoim rozmówcą mogą go lepiej zrozumieć i poznać. Przybliża zatem inne kultury, uczy kontaktu z obcym, z nieznanym, a także pozwala na walkę z uprzedzeniami, stereotypami i niechęcią wobec innych.

Z powodu współczesnych przemian migracyjnych Europa potrzebuje mieszkańców, którzy będą rozumieli różne języki i kultury, którzy będą potrafili działać wśród tych kultur. Dewiza Unii Europejskiej, ogłoszona na sesji Parlamentu Europejskiego 4 maja 2000 roku, brzmi w wersji łacińskiej: In varietate concordia. Oficjalne jej tłumaczenie w języku polskim brzmi: Zjednoczeni $w$ różnorodności. To idea rozumienia różnorodności obyczajów, przekonań i języków. Język jest bowiem najistotniejszym nośnikiem kultury, daje poczucie tożsamości, ma wpływ na rozwój naszej osobowości. Im większa będzie świadomość kulturowa i językowa ludzi, tym bardziej będą zmotywowani do poznania zróżnicowanego, wielowymiarowego i wielokulturowego świata. Konsekwencją takiego poglądu było m.in. ogłoszenie przez Parlament Europejski i Radę Europejską roku 2001 Europejskim Rokiem Języków. Głównym jego celem było zachęcenie wszystkich mieszkańców państw członkowskich Unii Europejskiej do uczenia się języków, poprzez ukazanie korzyści kulturalnych, edukacyjnych, ekonomicznych i osobistych płynących z nauki języków europejskich w ciągu całego życia ${ }^{1}$.

1 W. Rabczuk: O potrzebie rewaloryzacji języków mniej rozpowszechnionych. W: T. Lewowicki, E. Ogrodzka-Mazur, A. Gajdzica (red.): Świat wartości i edukacja międzykulturowa. Cieszyn - Warszawa 2003, UŚ - Filia w Cieszynie, Wyższa Szkoła Pedagogiczna ZNP w Warszawie, s. 122-123. 
Zaprezentowane $\mathrm{w}$ artykule badania zostały przeprowadzone w trakcie trwania projektu Akcent@com, który miał m.in. na celu zintensyfikowanie współpracy transgranicznej instytucji edukacyjnych działających w sześciu euroregionach położonych wzdłuż granicy polsko-czeskiej poprzez organizację wspólnych warsztatów. Ich tematyka oscylowała wokół edukacji międzykulturowej, rozwoju kompetencji komunikacyjnej w językach krajów sąsiadujących, a także tworzenia sieci partnerskiej mogącej w przyszłości realizować wspólne przedsięwzięcia edukacyjne. Uniwersytet Śląski brał w nim udział jako jeden z partnerów. Projekt był realizowany w ramach Programu Europejska Współpraca Terytorialna - Współpraca Transgraniczna Polska-Czechy.

Celem prezentowanych badań było poznanie samooceny kompetencji językowej w zakresie znajomości języka sąsiadów młodzieży z euroregionów pogranicza polsko-czeskiego, działań, jakie podejmuje w celu nauki tego języka, a także diagnoza barier, które ograniczają rozwój badanych sprawności językowych. Samoocena młodzieży mieszkającej na terenie euroregionów: Śląsk Cieszyński, Silesia, Pradziad, Nysa, Beskidy, Glacensis (etnicznych Polaków i Czechów mieszkających w tych euroregionach po obu stronach granicy) odnosiła się do oceny swojej kompetencji językowej w zakresie sprawności dotyczących: czytania, pisania, mówienia i rozumienia w języku mieszkańców sąsiedniego państwa.

\section{Kompetencja językowa - znaczenie pojęcia}

Jedno z czterech znaczeń słowa „kompetencja” zaprezentowanych w Słowniku Wyrazów Obcych określa ją jako „zakres czyjejś wiedzy, umiejętności, odpowiedzialności”2. Oznacza to, że mówiąc o czyjejś kompetencji, musimy dokładnie określić ów zakres, ową dziedzinę, w której dana osoba jest kompetentna. Można tym samym dysponować wieloma różnymi kompetencjami. W opinii I. Kurcz „kompetencje związane z mową, językiem, porozumiewaniem się tworzą pewnego rodzaju hierarchie i pozostają we wzajemnych zależnościach" ${ }^{3}$. Można zatem jej zdaniem wyróżnić ogólną kompetencje symboliczna, tzn. zdolność wielu żywych organizmów do przypisywania znaczenia różnego rodzaju znakom w rezultacie procesu uczenia się, ale -

2 Stownik wyrazów obcych. Warszawa 2010, PWN, s. 372.

3 I. Kurcz: Dwujęzyczność a język globalny. W: M. Pawlak, M. Derenowski, B. Wolski (red.): Problemy wspótczesnej dydaktyki języków obcych. Poznań - Kalisz 2009, UAM, s. 13. 
jak zauważa - kompetencja ściśle językowa jest właściwa tylko człowiekowi i na tyle złożona, iż wymaga specyficznych ośrodków mózgowych dla swego funkcjonowania, a ich uszkodzenie powoduje określone zaburzenia w tym funkcjonowaniu. Jeśli zatem kompetencją jest zakres umiejętności w jakiejś dziedzinie, to można sobie wyobrazić, że ludzie będą różnili się tymi zakresami i jedni będą wybitnie lepsi od innych ${ }^{4}$.

Kompetencja językowa uczącego się przejawia się w działaniach językowych. W opinii autorów Europejskiego systemu terminem tym zwykło się określać to, co powszechnie nazywamy „czterema podstawowymi sprawnościami językowymi”: rozumienie, mówienie, czytanie, pisanie, jednakże widziane pod innym kątem. Przyjmuje się, że sprawność należy tutaj rozumieć raczej jako zespół umiejętności niezbędnych do osiągnięcia danego rezultatu niż sam rezultat ${ }^{5}$. Wówczas termin działania odsyła nas do pewnej grupy działań. Odróżnić można zatem działania recepcji od działań produkcji, jak również te, które następują pod wpływem bodźca słuchowego, od tych, które pojawiają się w wyniku bodźca wzrokowego, a to prowadzi do tradycyjnego czteroczęściowego podziału. Istnieje także inny podział, w którym można odróżnić działania jednokierunkowe, w których uczący się/użytkownik języka podejmuje działania produkcji lub recepcji tekstu ustnego czy pisanego (rozumienie, mówienie czytanie i pisanie), od tych, w których uczący się/ użytkownik języka podejmuje się roli produkowania i odbioru tekstów (działania interakcyjne, w czasie których następuje wymiana słowna z rozmówcą (np. konwersacja) i działania mediacji, w których uczący się/użytkownik języka służy jako kanał komunikacyjny pomiędzy innymi rozmówcami (np. w charakterze tłumacza). Na ogół uważa się, że recepcja jest bardziej prosta od produkcji, która z kolei jest łatwiejsza od interakcji, a ta z kolei od mediacjí.

W zaprezentowanych w niniejszym artykule badaniach przyjęto tradycyjny podział kompetencji językowej na cztery sprawności: czytanie, rozumienie, mówienie i pisanie.

4 Tamże.

5 Rada Europy: Europejski system opisu ksztatcenia językowego: uczenie się, nauczanie, ocenianie. Warszawa 2003, CODN.

6 I. Janowska: Zadanie, ćwiczenie, działanie językowe - wzajemne relacje $i$ implikacje w dydaktyce jezykowej. W: M. Pawlak, M. Derenowski, B. Wolski (red.): Problemy współczesnej dydaktyki języków obcych. cyt. wyd., s. 124. 


\section{Samoocena - rozważania teoretyczne}

Żyjemy dziś w świecie przepełnionym konsumpcjonizmem, w którym na co dzień młodego człowieka spotyka konkurencja i współzawodnictwo. Wyznacza sobie zatem ciągle cele, które - jak się mu wydaje - dadzą mu gwarancję życiowego sukcesu, przewagę nad innymi, popularność, pozwolą znaleźć swoje miejsce w świecie, czy też umożliwią mu samorealizację i doskonalenie się. Jednak ciągłe zmiany i szybki postęp techniczny sprawiają, że nie ma on czasu na głębszą refleksję nad sobą, nad własną wartością. „Obraz samego siebie kształtuje się nie tylko na podstawie tego, jak inni nas traktują, lecz także poprzez porównanie siebie z innymi podobnymi do nas osobami: rówieśnikami tej samej płci, tej samej rasy czy klasy społecznej. Porównania dotyczą wyglądu fizycznego, zdolności, wierzeń i przekonań, zawodowych osiągnięć, popularności w grupie i tym podobnych cech. Podobieństwo determinowane jest przez przynależność do tej samej grupy, zwanej grupą odniesienia"7.

Poczucie Ja obejmuje zatem nie tylko wiedzę o tym, kim jestem, lecz zawiera także element emocjonalno-oceniający. Wyraża się on w odczuciach dotyczących tego, czy i w jakim stopniu dana osoba uważa się za wartościową. Aspekt ten jest określany mianem samooceny. Samoocena jest oszacowaniem własnej wartości. Mówi się też o niej jako o postawie wobec siebie ${ }^{8}$. Większość współczesnych badaczy zgadza się, że samoocena jest afektywną reakcją na siebie samego i ma dwoistą naturę procesu i cechy. Z jednej strony ma własności cechy, czyli trwałego ustosunkowania się jednostki do samej siebie, którym ludzie różnią się między sobą - niektórzy mają samoocenę negatywną, inni zaś - mniej lub bardziej pozytywną. Takie jej rozumienie pozwala na dokonywanie pomiarów i badań, od czego zależy, na co ma wpływ oraz czemu służy. Z drugiej strony samoocena jest procesem bieżącego wartościowania własnej osoby ukierunkowanym na cel, jaki stanowi pozytywny wniosek na własny temat. Cel ten jest dla większości osób bardzo pożądany, gdyż zależy nam na tym, by dochodzić do pozytywnych wniosków na własny temat ${ }^{9}$.

7 W. Wosińska: Psychologia życia społecznego. Podręcznik psychologii społecznej dla praktyków i studentów. Gdańsk 2004, GWP, s. 59.

8 Tamże, s. 59.

9 B. Wojciszke: Psychologia społeczna. Warszawa 2014, Scholar, s. 175. 


\section{Wyniki badań własnych}

W prezentowanych badaniach samoocena młodzieży mieszkającej na terenie euroregionów: Śląsk Cieszyński, Silesia, Pradziad, Nysa, Beskidy, Glacensis odnosi się do oceny swojej kompetencji językowej w zakresie sprawności dotyczących: czytania, pisania, mówienia i rozumienia w języku mieszkańców sąsiedniego państwa. Ze względu na szkolne doświadczenia ciągłego poddawania ocenie ich różnego rodzaju kompetencji przez nauczycieli, wydaje się, że było to dla badanych zadanie dość trudne. Tym bardziej, że oceniali kompetencję w obrębie języka, którego systematyczny i sformalizowany sposób nauki pojawia się w ich życiu bardzo rzadko lub w ogóle. Podejmując to zagadnienie sformułowano zatem następujące problemy badawcze:

- Czy i jakie działania podejmuje młodzież w celu nauki języka czeskiego/polskiego?

- Jak badani oceniają stopień opanowania kompetencji językowej w zakresie czytania, rozumienia, mówienia i pisania?

- Jakie bariery ograniczające rozwój kompetencji językowej w zakresie języka sąsiada zauważają młodzi ludzie?

Metodą, która została zastosowana w badaniach, był sondaż diagnostyczny. Prowadząc sondaż diagnostyczny, posłużono się techniką ankiety, która został przeprowadzona w drugiej połowie 2015 roku.

Wykres 1. Liczba badanych w poszczególnych euroregionach

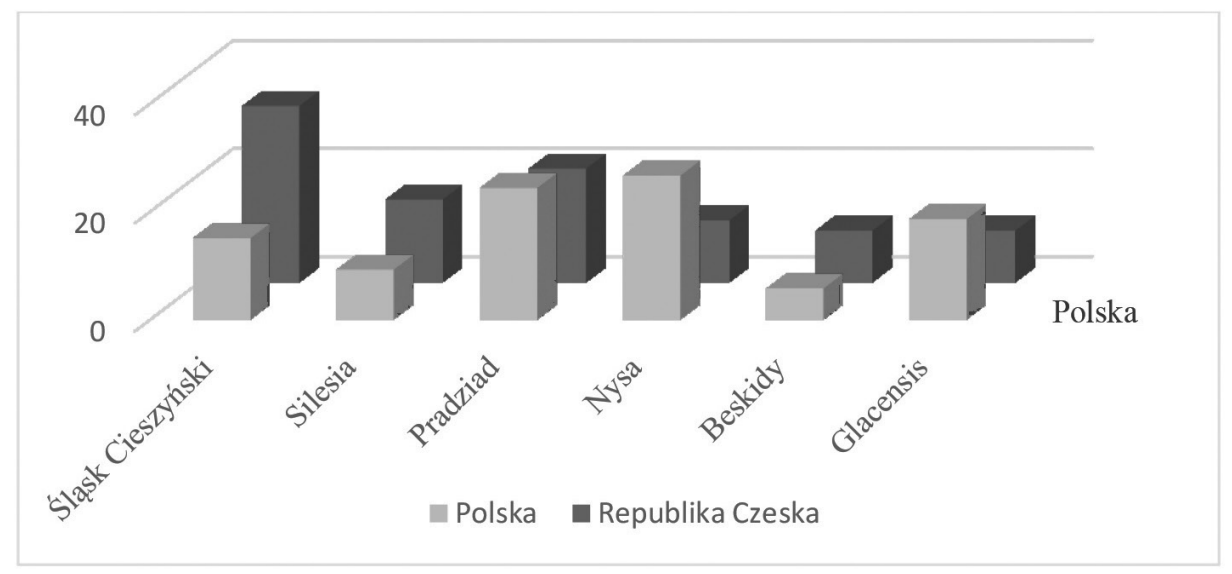

Źródło: badania własne. 
W badaniu wzięło udział 138 uczniów ze szkół ponadgimnazjalnych z pogranicza polsko-czeskiego, w tym 86 Polaków i 52 osoby z Czeskiej Republiki. Na wykresie 1 przedstawiono dane dotyczące zamieszkania respondentów w euroregionach objętych badaniem.

Udział badanych ze względu na ich miejsce zamieszkania w poszczególnych euroregionach na terenie macierzystych państw był zróżnicowany. Połowa badanych uczniów z Polski mieszka na terenie euroregionów Nysa (26\%) i Pradziad (24\%). 19\% pochodzi z Glacensis, 15\% ze Śląska Cieszyńskiego, 10\% ze Silesji, a 6\% z Beskidów. W Republice Czeskiej najliczniejsza grupa młodzieży wywodzi się ze Śląska Cieszyńskiego (33\%), 21\% to uczniowie z Pradziada, 15\% ze Silesji, 12\% z Nysy, a z Beskidów i Glacensis po 9\% badanych.

Rozpoczynając analizę zebranego materiału badawczego, na wykresie 2 przedstawiono wyniki badań dotyczące działań, jakie podejmuje badana młodzież w celu nauki języka czeskiego lub polskiego.

Wykres 2. Miejsce zamieszkania a działania podejmowane w celu nauki j. polskiego/ czeskiego

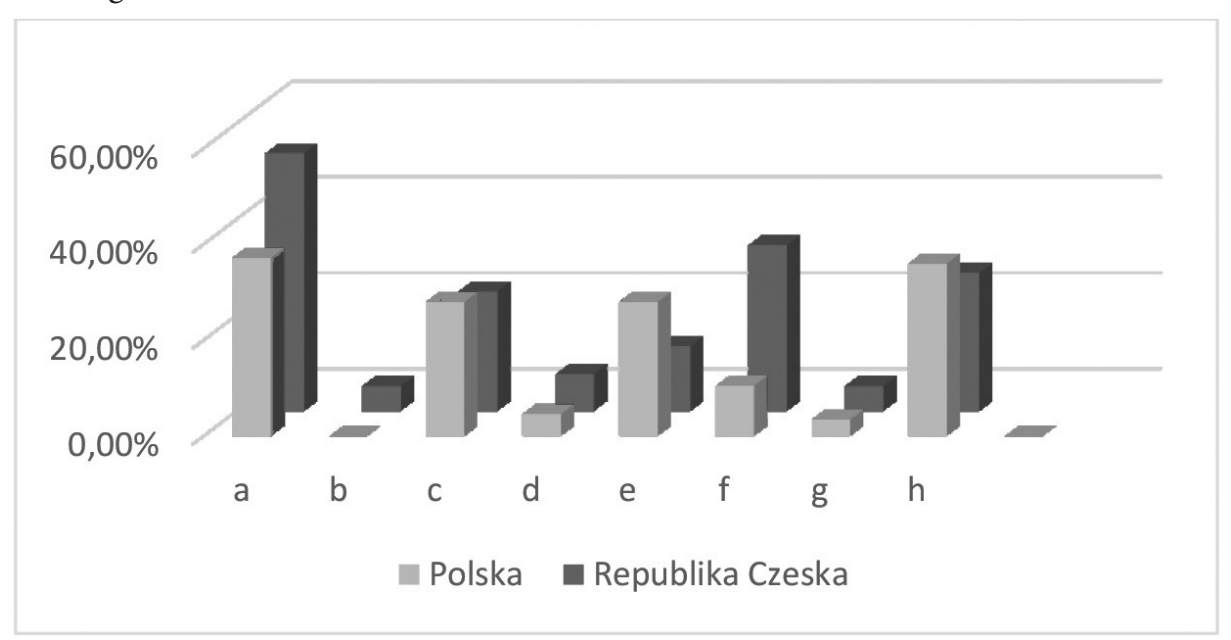

Legenda: a - ogląda programy telewizyjne $\mathrm{w}$ j. polskim/czeskim; b - uczestniczy w kursie językowym; c - współpracuje lub wyszukuje współpracy z polskim/czeskim sąsiadem; d - czyta gazety $\mathrm{w} j$. polskim/ czeskim; e - korzysta z internetu w j. polskim/ czeskim; $\mathrm{f}$ - rozmawia ze znajomymi w $\mathrm{j}$. polskim/czeskim; $\mathrm{g}$ - inne działania; $\mathrm{h}$ - nie podejmuje żadnych działań.

Źródło: badania własne. 
Jak można zauważyć, aż 36,6\% Polaków i 28,8\% Czechów nie podejmuje żadnych działań w celu nauki języka mieszkańców sąsiedniego kraju. Natomiast ponad połowa $(53,8 \%)$ czeskiej młodzieży uczy się języka, oglądając programy telewizyjne (w Polsce $37,2 \%$ ), 34,6\% rozmawia ze znajomymi w języku polskim (10,5\% Polaków rozmawia w języku czeskim), a co czwarta osoba badana z Republiki Czeskiej współpracuje lub szuka współpracy z Polakami (28\% badanych w Polsce). Ponad dwukrotnie więcej polskiej młodzieży (28\%) korzysta z internetu w języku urzędowym sąsiedniego kraju. Należy również podkreślić, że niestety wśród badanej młodzieży z Polski nikt nie uczestniczy w regularnych kursach języka czeskiego, a zaledwie 5,2\% młodych ludzi po czeskiej stronie granicy wybiera taki sposób nauki języka polskiego.

Na kolejnych czterech wykresach zaprezentowano samoocenę badanej młodzieży w zakresie czterech wyróżnionych sprawności, uwzględniając ich miejsce zamieszkania.

Wykres 3. Miejsce zamieszkania a samoocena stopnia opanowania sprawności czytania w języku sąsiadów

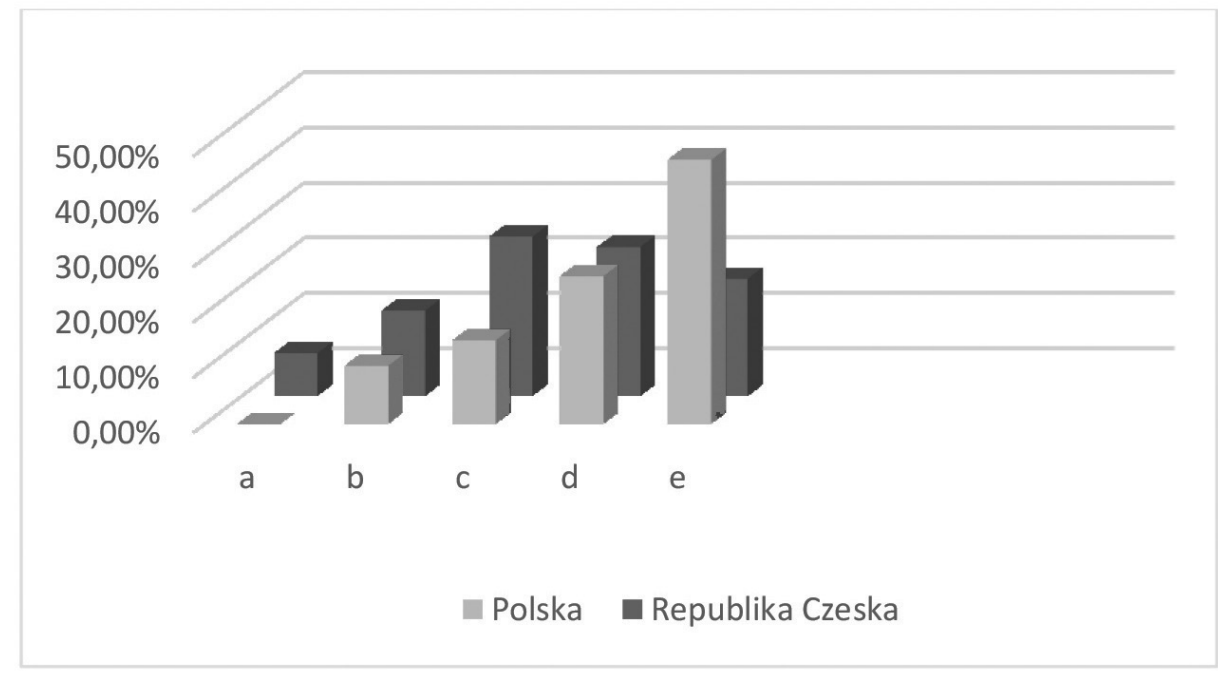

Legenda: a - bardzo dobry; b - dobry; c - dostateczny; d - słaby; e - bardzo słaby Źródło: badania własne.

Czytanie w języku mieszkańców sąsiedniego państwa należy do umiejętności, których stopień opanowania najwięcej polskiej młodzieży ocenia jako 
bardzo słaby $(47,7 \%)$, następnie słaby $-26,7 \%$, dostateczny $-15,1 \%$, a tylko 10,5\% jako dobry. Z kolei najwięcej badanej młodzieży czeskiej uważa, że dobrze potrafi czytać w języku polskim $(28,8 \%)$ lub - niewiele mniej - słabo (26,9\%). Bardzo słabo - ich zdaniem - opanowało tę umiejętność $21,1 \%$ spośród nich, 15,4\% - dostatecznie i o połowę mniej - bardzo dobrze.

Wyniki te potwierdzają, że badani nie biorą udziału w systematycznej nauce języka sąsiadów, gdyż czytanie to sprawność, którą najlepiej można doskonalić w bezpośrednim kontakcie z osobą kontrolującą postępy uczącego się, dokonywać niezbędnych poprawek w identyfikacji symboli graficznych w obcym języku, ich wymowie i akcencie.

Rozumienie to sprawność, której stopień opanowania badani ocenili najwyżej. I tak wśród Polaków 36\% stawia sobie ocenę dopuszczającą, ale już co czwarty - dostateczną, 17,4\% - dobrą, a 1,2\% - bardzo dobrą. Najwięcej badanej młodzieży z Republiki Czeskiej $(34,6 \%)$ uważa, że rozumie mowę sąsiadów w stopniu dostatecznym, 15,5\% - dobrym, a 11,5\% w bardzo dobrym. Niestety bardzo słabo oceniło opanowanie tej sprawności 21\% Polaków i 11,5\% Czechów.

Wykres 4. Miejsce zamieszkania a samoocena stopnia opanowania sprawności rozumienia w języku sąsiadów

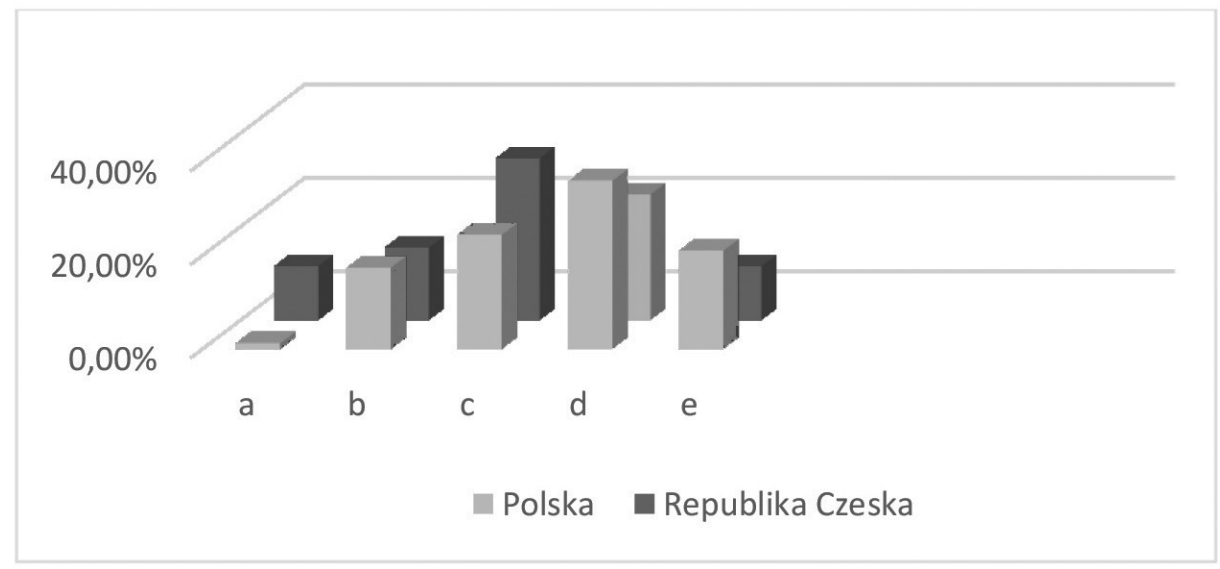

Legenda: a - bardzo dobry; b - dobry; c - dostateczny; d - słaby; e - bardzo słaby Źródło: badania własne. 
Wykres 5. Miejsce zamieszkania a samoocena stopnia opanowania sprawności w zakresie mówienia w języku sąsiadów

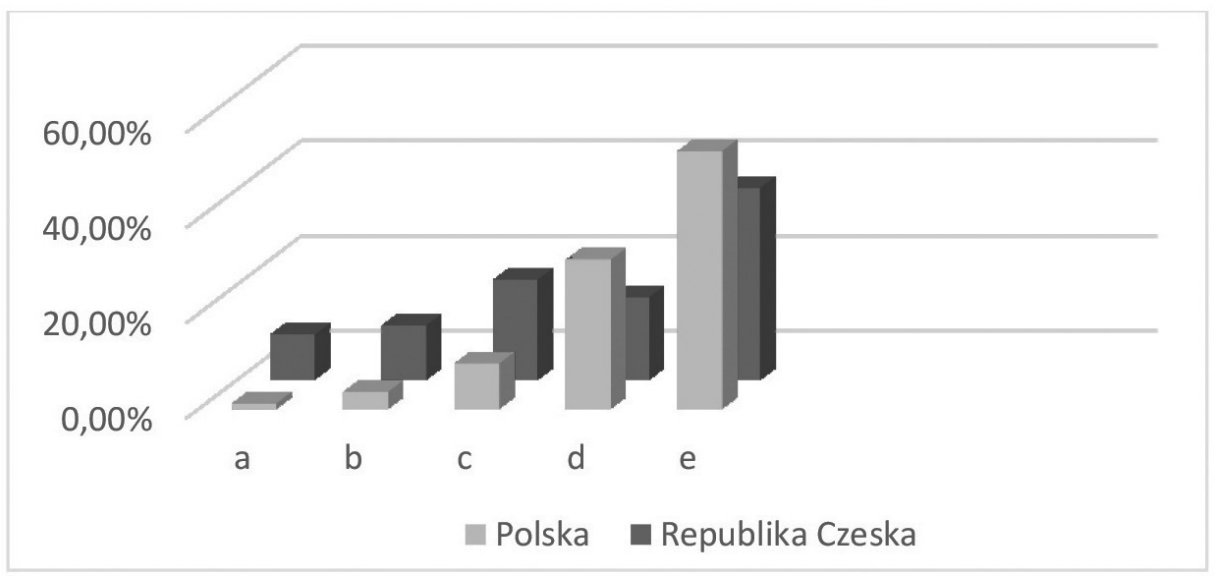

Legenda: a - bardzo dobry; b - dobry; c - dostateczny; d - słaby; e - bardzo słaby Źródło: badania własne.

Uzyskane rezultaty można wyjaśnić rodzajem deklarowanych działań podejmowanych przez badanych w celu kontaktu z językiem sąsiadów. Jest to przede wszystkim kontakt jednostronny za pośrednictwem mediów (programy telewizyjne, Internet), co przede wszystkim rozwija sprawność rozumienia, lub - zdecydowanie mniej - bezpośredni kontakt ze znajomym z zagranicy, podczas którego również wymagane jest efektywne rozumienie przekazywanych treści.

Posługiwanie się językiem w mowie to sprawność, której opanowanie młodzież z Polski ocenia niżej niż ich koledzy z Republiki Czeskiej. Ponad połowa $\mathrm{z}$ nich $(54,2 \%)$ uważa, że w bardzo słabym stopniu potrafi posługiwać się w mowie językiem czeskim, 31,4\% - słabym, 9,6\% - dostatecznym, a zaledwie 3,6\% ocenia posiadanie tej kompetencji w stopniu dobrym i tylko jedna osoba - bardzo dobrym. Po stronie czeskiej 40,4\% badanych jest zdania, że opanowało tę sprawność w stopniu bardzo słabym, 21,4\% - dostatecznym, 17,4\% - słabym, natomiast $11,5 \%$ - dobrym, a 9,6\% - bardzo dobrym.

Ocena, jaką wystawili sobie badani za opanowanie tej sprawności, jest bardzo niska. Jak sami wcześniej wskazali, nie podejmują żadnych działań w celu nauki języka mieszkańców sąsiedniego państwa lub jest to raczej kontakt bierny (poprzez media), który nie wymaga od nich podejmowania żadnych działań kształtujących sprawność posługiwania się językiem obcym w mowie. 
Wykres 6. Miejsce zamieszkania a samoocena stopnia opanowania sprawności w zakresie pisania w języku sąsiadów
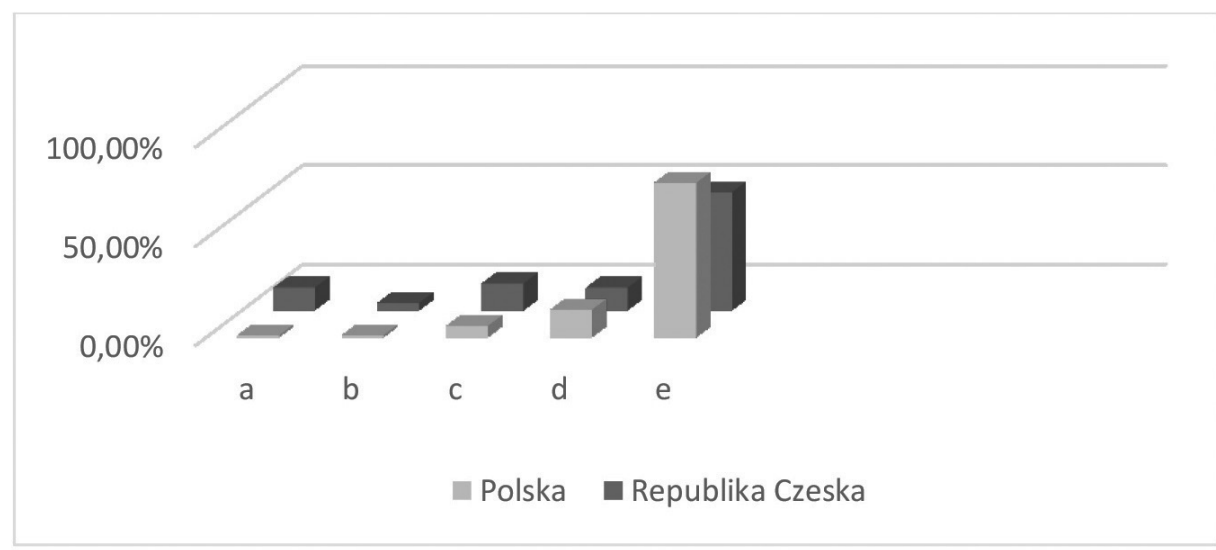

Legenda: a - bardzo dobry; b - dobry; c - dostateczny; d - słaby; e - bardzo słaby Źródło: badania własne.

Wykres 7. Miejsce zamieszkania a bariery ograniczające rozwój kompetencji językowej w zakresie języka sąsiada

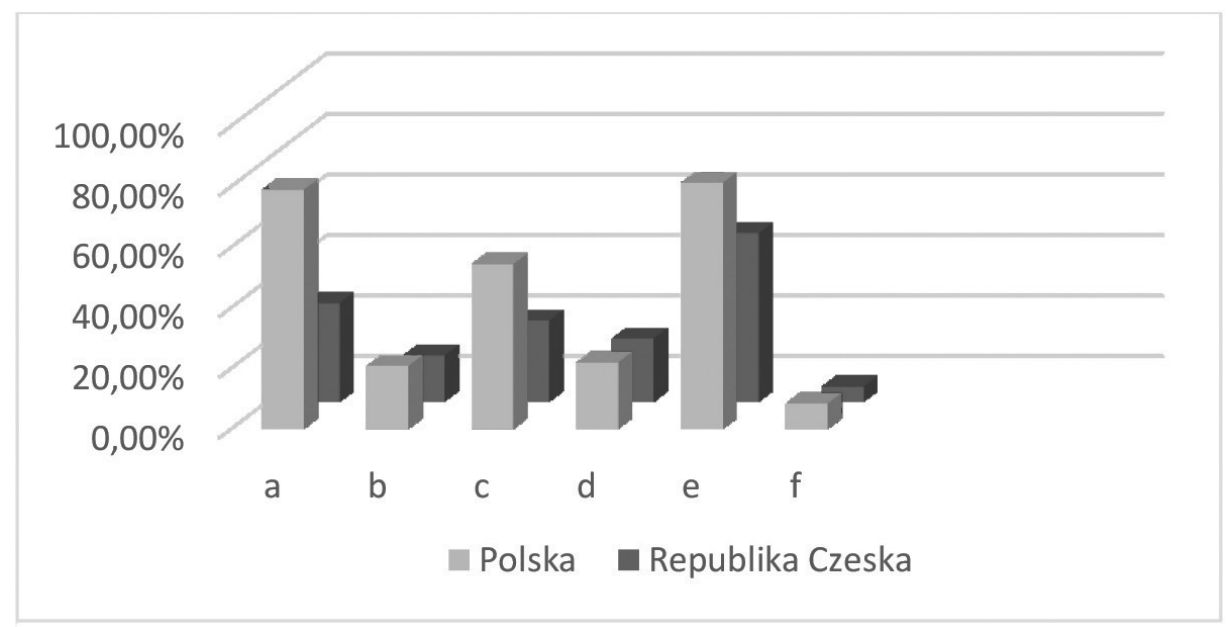

Legenda: a - brak kursów j. polskiego/czeskiego; b - kursy językowe są za drogie; c - języki te są bardzo podobne do siebie i nie dostrzega konieczności uczestnictwa w kursach; d - niechęć do nauki j. polskiego/czeskiego; e - brak potrzeby lub motywacji do doskonalenia się $\mathrm{w} \mathrm{j}$. polskim/ czeskim, $\mathrm{f}$ - inne Źródło: badania własne. 
Posługiwanie się językiem sąsiada na piśmie to sprawność, której posiadanie badani ocenili najsłabiej. Ponad połowa Czechów $(59,6 \%)$ i aż $78 \%$ Polaków uważa, że opanowało ją w stopniu bardzo słabym, a 11,5\% z Republiki Czeskiej i 14\% z Polski jest zdania, że w stopniu słabym. Zaledwie 13,6\% młodzieży czeskiej stawia sobie ocenę dostateczną, niewiele mniej (11,5\%) - bardzo dobrą i 3,8\% - dobrą. 5,8\% polskiej młodzieży oceniło się dostatecznie i tylko po pojedyncze osoby dobrze i bardzo dobrze.

Pisanie - podobnie jak czytanie - to złożone czynności umysłowe, których nabywanie należy do skomplikowanych procesów. Jeżeli młodzi ludzie nie podejmują systematycznych działań w celu nauki języka, to stopień ich opanowania ocenili rzeczywiście nisko. W dużej mierze jednak od poziomu opanowania czytania i pisania w danym języku zależy, jak sprawnie będą się posługiwali nim jako narzędziem komunikacji i poznawania.

Ostatnim zagadnieniem będącym przedmiotem badania są bariery, które - zdaniem badanych - mogą ograniczać rozwój kompetencji językowej w zakresie języka polskiego/czeskiego.

Młodzież po obu stronach granicy jest bardzo jednomyślna. Okazuje się bowiem, że najczęściej wybieranym powodem - zarówno przez Polaków $(81,4 \%)$, jak i Czechów $(55,8 \%)$ - był brak potrzeby i motywacji do doskonalenia się w języku czeskim/polskim. Kolejnymi barierami okazały się: brak kursów doskonalących nabywanie tej kompetencji (79,1\% młodych ludzi z Polski i 32,7\% z Republiki Czeskiej), podobieństwo języków do siebie, a zatem niedostrzeganie konieczności uczestnictwa w dodatkowych kursach $(54,6 \%$ Polaków i 26,9\% Czechów), a także zbyt wysoka cena kursów (21\% młodzieży z Polski i 22,1\% z Republiki Czeskiej) i niechęć do nauki języka sąsiada (22,1\% Polaków i 21,1 Czechów). Jak można zauważyć, główna przyczyna ograniczająca rozwój sprawności językowych w zakresie języka czeskiego/polskiego tkwi w samej młodzieży, która nie widzi potrzeby lub nie ma motywacji, a nawet - co piąty badany - żywi niechęć do jej doskonalenia.

Wyniki te potwierdzają bardzo małe zainteresowanie badanych nauką języka rówieśników zza sąsiedniej granicy, a więc i brak działań z ich strony, które pozwoliłyby na doskonalenie sprawności posługiwania się językiem polskim/czeskim w mowie i piśmie.

\section{Podsumowanie}

Współcześnie wraz z rosnącą koniecznością nauki języków obcych wzrastają także perspektywy ich nauki. Dzięki dostępnym środkom multimedialnym 
młodzi ludzie dysponują wręcz nieograniczonymi możliwościami ich nauki. Aktualnie nie pytamy już, czy warto i jakich języków się uczyć, ale ilu i w jakiej formie. Jednak, jak można zauważyć w większości europejskich społeczeństw i w ramach ich polityki oświatowej, istotna jest znajomość przede wszystkim takich języków jak: angielski, niemiecki, francuski, łacina oraz coraz częściej - hiszpański i włoski. Oferta językowa powinna jednak zdecydowanie wykraczać poza tę tradycyjną klasyfikację. Europie potrzebni są obywatele, którzy nie tylko znają języki obce, lecz są wielojęzyczni. Niestety, znajomość języka polskiego dla młodzieży z Republiki Czeskiej i czeskiego dla polskiej nie jest atrakcyjna. Badani nie dostrzegają bowiem konieczności, nie mają również motywacji do tego, aby rozwijać sprawności językowe w zakresie języka mieszkańców sąsiedniego państwa, a niektórzy są wręcz niechętni do tego. Stąd też młodzi ludzie nie podejmują żadnych działań lub robią to sporadycznie - w celu jego nauki w czasie kursów językowych lub w inny sposób (wykres 2). Dla większości z nich najbardziej motywującą formą jego poznania okazały się oglądanie programów telewizyjnych, współpraca lub swobodne rozmowy (przede wszystkim młodzież czeska) z sąsiadem zza granicy, a także przeglądanie stron internetowych. Są to jednak działania sporadyczne. Nie dziwi zatem niska ocena opanowania poszczególnych sprawności językowych, jaką wystawiła sobie większość badanych. Nie pomógł nawet fakt, że ponad połowa Polaków i 26,9\% Czechów uważa, że istnieje bardzo duże podobieństwo języków do siebie.

W każdej z poddanych ocenie sprawności językowej zdecydowanie więcej młodych ludzi z Polski niż Republiki Czeskiej oceniło ich opanowanie na słabym lub bardzo słabym poziomie, a mniej na dobrym lub bardzo dobrym. I tak w zakresie czytania najniższe oceny wystawiło sobie 74,7\% Polaków i 48\% Czechów, w przypadku rozumienia - 57\% polskiej młodzieży i 38,4\% czeskiej, mówienie w języku czeskim to słabość $85,6 \%$ badanych, a w polskim - 57,8\%, do słabego lub bardzo słabego pisania w języku sąsiadów przyznało się aż 92\% Polaków i 71,1\% Czechów.

Sprawnością, której opanowanie najwięcej ankietowanych z Polski oceniło na poziomie dobrym lub bardzo dobrym, było rozumienie $(18,6 \%, 27 \%$ młodzieży czeskiej), a z Republiki Czeskiej - czytanie (36,5\%, 10,5\% młodzieży polskiej). Mówienie po czesku na co najmniej dobrym poziomie oceniło $4,8 \%$ Polaków, a po polsku ponad cztery razy więcej Czechów (21,1\%). Niestety zaledwie 2,2\% młodych ludzi z polskich szkół potrafi pisać w stopniu dobrym lub bardzo dobrym w języku czeskim, a 15,3\% z czeskich szkół w języku polskim. 
Jak można zauważyć, zdecydowanie częściej czeska młodzież uważa, że opanowała poszczególne sprawności językowe na co najmniej dobrym poziomie. Może to być związane z tym, że po czeskiej stronie granicy więcej młodzieży ogląda polskie programy lub praktykuje je w bezpośredniej relacji z sąsiadami. Aby udoskonalić rozwój tych sprawności, należy przede wszystkim zadbać o motywację do nauki tych języków, ponieważ specyfiką nauki języków obcych jest to, że brak szybkich efektów i realnych możliwości ich wykorzystania może zniechęcić nawet tych, którzy są bardzo pozytywnie nastawieni do nauki. Poza tym wymaga wysokich nakładów energii, cierpliwości i systematyczności. Elementy specyfiki tego kształcenia określiła M. Marcinkowska-Bachlińska, wymieniając:

- konieczność odpowiedniego treningu w zakresie czterech podstawowych sprawności językowych: czytania, mówienia, rozumienia i pisania;

- potrzebę treningu komunikacyjnego, wynikającą z interakcyjno-komunikacyjnego wymiaru działań językowych, powiązanych ze społecznym używaniem języka;

- kształtowanie odrębnego systemu pojęć i wyrażania myśli zgodnie z mentalnością użytkowników danego języka,

- konieczność petnego zaangażowania w procesie nauczania „całego ucznia”, jego osobowości i potencjału intelektualno-społecznego, związaną z psychiczno-mentalno-motorycznym wymiarem działań językowych;

- radzenie sobie z komunikacją obcojęzyczną podejmowaną przy niepełnej kompetencji językowej;

- wykształcenie kompetencji uczeniowej, jako podstawy dalszego samodoskonalenia komunikacyjnego ${ }^{10}$.

Należałoby zatem stwarzać młodzieży jak najwięcej możliwości bezpośrednich kontaktów z rówieśnikami zza granicy poprzez organizowanie wymian międzyszkolnych, wyjazdów krajoznawczych, różnego rodzaju warsztatów integracyjnych czy też wspólnych działań artystycznych lub sportowych. Niezwykle istotne jest bowiem dla młodych ludzi, aby powiązać naukę języka obcego z przyjemnością, z poznawaniem nowych ludzi i ich kultury. Prowadzić to będzie do zrozumienia drugiego człowieka - sąsiada, a co za tym idzie - pozytywnego nastawienia do dziedzictwa kulturowego jego kraju.

10 M. Marcinkowska-Bachlińska: Psychologiczne czynniki wptywające na poziom motywacji do nauki języka obcego. http://www.kms.polsl.pl/prv/spnjo/referaty/marcinkowska-bachlinska.pdf. 
Francuski lingwista C. Hagege jest nawet zdania, że w europejskich szkołach powinno się dokonywać wyborów spośród pięciu języków: niemieckiego, hiszpańskiego, francuskiego, włoskiego, portugalskiego, ale także języków sąsiadów, które są niezbędne w kontaktach z nimi ${ }^{11}$.

Warto zatem zachęcać do organizowania - po obu stronach granicy większej liczby propozycji lektoratów, podczas których możliwe będzie poznawanie kultury i języka sąsiadów, szczególnie w ramach różnego rodzaju zajęć dodatkowych na terenie szkół lub w szkołach językowych w formie kursów. Oczywiście wszystkie te działania muszą być poprzedzone pozytywnym umotywowaniem i pokazaniem młodym ludziom realnych korzyści wynikających z podjęcia takiego wysiłku, gdyż nie tylko trening prowadzony przez doświadczonego nauczyciela, ale aspekt emocjonalno-motywacyjny decyduje o tym, czy rzeczywiście młodzi nabędą te sprawności w stopniu umożliwiającym im swobodną komunikację z sąsiadem z zagranicy.

Mimo że w badanych euroregionach nauka języka mieszkańców sąsiedniego kraju jest ułatwiona ze względu na bardzo bliską odległość między oba państwami i - jak sami badani podkreślają - ich podobieństwo, młodzi ludzie niechętnie się jej podejmują. Bardzo dobrą okazją promującą i zachęcającą młodzież do poznania kultury i języka „sąsiadów” był projekt Akcent@com, w ramach którego zostały przeprowadzone zaprezentowane badania. Pozwolił on na stworzenie po obu stronach granicy sieci partnerskich szkół, które mogą w przyszłości realizować wiele wspólnych przedsięwzięć edukacyjnych. Stał się swego rodzaju pozytywnym impulsem do dalszej współpracy transgranicznej. Wszystko jednak zależy od kreatywności, zaangażowania, a przede wszystkim chęci samych nauczycieli i uczniów. Takich projektów powinno być zdecydowanie więcej.

\section{Bibliografia}

Janowska I.: Zadanie, ćwiczenie, działanie językowe - wzajemne relacje $\mathrm{i}$ implikacje w dydaktyce językowej. W: M. Pawlak, M. Derenowski, B. Wolski (red.): Problemy współczesnej dydaktyki języków obcych. Poznań - Kalisz 2009, UAM.

11 W. Rabczuk: O potrzebie rewaloryzacji języków mniej rozpowszechnionych. W: T. Lewowicki, E. Ogrodzka-Mazur, A. Gajdzica (red.): Świat wartości i edukacja międzykulturowa. cyt. wyd. 
Kurcz I.: Dwujęzyczność a język globalny. W: M. Pawlak, M. Derenowski, B. Wolski (red.): Problemy wspótczesnej dydaktyki języków obcych. Poznań - Kalisz 2009, UAM.

Marcinkowska-Bachlińska M.: Psychologiczne czynniki wptywajace na poziom motywacji do nauki języka obcego. http://www.kms.polsl.pl/prv/spnjo/referaty/marcinkowska-bachlinska.pdf

Rabczuk W.: O potrzebie rewaloryzacji języków mniej rozpowszechnionych. W: T. Lewowicki, E. Ogrodzka-Mazur, A. Gajdzica (red.): Świat wartości i edukacja międzykulturowa. Cieszyn - Warszawa 2003,UŚ - Filia w Cieszynie, Wyższa Szkoła Pedagogiczna ZNP w Warszawie.

Rada Europy: Europejski system opisu ksztatcenia językowego: uczenie się, nauczanie, ocenianie. Warszawa 2003, CODN.

Stownik wyrazów obcych. Warszawa 2010, PWN.

Wojciszke B.: Psychologia społeczna. Warszawa 2014, Scholar.

Wosińska W.: Psychologia życia społecznego. Podręcznik psychologii społecznej dla praktyków i studentów. Gdańsk 2004, GWP.

\section{Self-assessment of the linguistic competence concerning the neighbours' language of the borderland youth from Polish-Czech euroregions}

\section{Summary}

Still in the second half of the $20^{\text {th }}$ century, learning foreign languages was mostly a domain of rich people, well-educated ones or those who performed specific professions. Today, what is important for the majority of European societies within their educational policies is the knowledge of such languages as: English, German, French, Latin, and - with growing frequency - of Spanish and Italian. It turns out, unfortunately, that such languages as Czech and Polish are not attractive for the young. With the use of a five-grade scale, the examined youth from the euroregions of the Polish-Czech borderland did the evaluation of the level of their acquisition of linguistic competence (in four basic skills: listening, reading, speaking and writing) in the language of the neighbouring country (Polish or Czech respectively). In each evaluated language skill, distinctly more young people from Poland than the Czech Republic assessed their competence as poor and fewer as good or very good. This might be related to the fact that, as research results have shown, in the Czech part of the borderland, more young people watch Polish programmes or practice the language in direct contacts with the neighbours. 
To enhance the development of the language skills, the appropriate motivation to learn these languages should be raised at first. This can be done by creating numerous possibilities of direct contacts with peers from abroad by organizing exchanges between schools, tourist trips, integration workshops or joint sport or artistic activities. What is crucial for the young is combining learning a foreign language with pleasure, meeting new people and familiarization with their culture.

Key words: linguistic competence, self-assessment of language skills, euroregions of Polish-Czech borderland 